\title{
Dominicans and Jesuits
}

\section{Introduction: Dominicans and Jesuits, through the Centuries}

\author{
Scott Steinkerchner, O.P. \\ Independent Scholar, Oak Park, IL, USA \\ steinkerchner@op.org
}

\begin{abstract}
This article interprets data from five key points in the relationship between the Order of Preachers (the Dominicans) and the Society of Jesus (the Jesuits) to develop guidelines about how this relationship can help or hinder the work of these two religious orders within the Roman Catholic Church. It concludes that conflictual relationships between the groups tend to hinder their work while collaborative relationships tend to amplify their work. The particular historical events studied are: early Dominican criticism of the Spiritual Exercises of Ignatius of Loyola; the different ways that Dominicans and Jesuits employed Mary in their dealings with Muslims in the sixteenth and seventeenth centuries; the de auxiliis controversy about the relationship between grace and free will; the founding of rival Dominican and Jesuit biblical schools at the beginning of the twentieth century; and the positive collaboration between Dominican Yves Congar and Jesuit Karl Rahner at the Second Vatican Council.
\end{abstract}

\section{Keywords}

Dominicans - Jesuits - Spiritual Exercises - Mary Mother of God - Muslims de auxiliis controversy - biblical schools - Yves Congar - Karl Rahner - Second Vatican Council 
Spanning the globe for five centuries, the Dominicans and the Jesuits have been related to each other in many different ways - as rivals, friends, distant cousins, co-workers, and sometimes even adversaries. It is impossible to create an overarching characterization of such various relationships that does it justice, but lessons can be learned by looking closely at some of these particular situations and how these relationship benefitted and hampered the work of the orders in various times and places, to the benefit and detriment of the wider church.

This issue of the Journal of Jesuit Studies draws together five vignettes of historical situations that hit many of the important moments in the collaborative and contentious relationship between Dominicans and Jesuits in order to give a broad view of the ways these two religious orders have related to each other, showing the positive and negative dynamics of this relationship and how this affects the benefits they have brought to the wider church.

The articles are arranged in chronological order but are related to each other in various ways. There are two longer articles about quintessential moments in the relationship: one from the beginning of the Jesuits, documenting early Dominican opposition to Ignatius's Spiritual Exercises, and one about their most bitter, long-standing theological argument over the relationship between nature and grace and free will, called the de auxiliis controversies. Then there are three shorter articles on other particularly interesting historical situations: the different ways Dominicans and Jesuits had recourse to Mary in their dealings with Muslims in the sixteenth and seventeenth centuries, the founding of rival Dominican and Jesuit schools of biblical studies at the beginning of the twentieth century, and the relationship between preeminent Dominican and Jesuit periti (experts) at the Second Vatican Council.

\section{Studying Biblical Studies}

Benedict Viviano's “Jesuit and Dominican Collaboration and Rivalry in Biblical Studies" is the shortest article, but it provides a spectrum of relationships on which we can locate all of the others. In the late nineteenth century, the Dominicans bumbled into some real estate just outside of the Damascus Gate of the Old City of Jerusalem and decided to turn the property into a school of biblical studies. The timing was right. The Ottoman Empire, which had ruled over biblical lands, was in decline and had granted Western Powers the right to establish consulates in Jerusalem. Pilgrims came pouring in, along with donors interested in commemorating the glory days of the crusades. The opening up of the Holy Land also renewed studies in biblical archeology, since one could 
simply ride out into a farmer's field and discover previously unknown inscriptions that could be used as new comparative material.

Dominican friar Marie-Joseph Lagrange (1855-1938) founded the École Biblique in Jerusalem in 1890 to take advantage of the moment. He had been studying Orientalism in Vienna, especially Hebrew, Arabic, and Assyriology, and was eager to start a new school that could study the Bible in its original context with reference to these ancient languages and cultures that were an integral part of its formation. This was the era of renewed biblical studies, and the École was positioned to take full advantage of the new situation. Other schools were also founded to take advantage of the new archeological opportunities as well, but the École was unique in having a stable body of teachers who resided there year-round, having a full library, and offering degrees or certificates for students.

Pope Leo XIII (1810-1903; r.1878-1903) was leading the church to embrace the changes in the modern world and created a biblical commission to advance biblical studies. The École began a scholarly journal and a monograph series dedicated to disseminating new findings in biblical scholarship. The Jesuits initially collaborated with Lagrange, but that ended when Pius x (18351914; r.1903-14) became pope and declared open war on what he deemed "Modernism" in both theology and biblical studies. Pius x sought to reverse Leo XIII's policies, filling the Biblical Commission with non-biblical theologians who mostly hindered biblical studies. The Jesuit superior general, seeking to readjust to the new papal politics, forbade his men to collaborate with Lagrange any more. The French Jesuits started their own rival journal. German Jesuit Leopold Fonck (1865-1930) attained the support of Pius X and moved to block Lagrange's projects. Fonck bought property in Jerusalem and attempted to start a rival biblical institute. Lagrange successfully argued that Jerusalem was too small to support two rival biblical schools, forcing the Jesuits to alter their plans, so in 1910, Fonck created the Pontifical Biblical Institute (commonly called the Biblicum) in Rome instead. By this time, biblical studies had become controversial. Being in Rome, the Biblicum could not take advantage of being on the site of much of what happens in the Bible, but it could take advantage of more papal protection than could the École. A new set of pontifical academic degrees was established that could only be conferred through the Pontifical Bible Commission or directly through the newly established Biblicum, and seminaries were pushed to use only professors credentialed by these new degrees. This gave the Biblicum a great advantage over the École in recruiting students.

The relationship between the École and the Biblicum remained contentious until 1943, when a Dominican student of Lagrange, Jacques Voste (1883-1949), 
collaborated with the Jesuit Augustin Bea (1881-1968) to help write the papal encyclical on biblical studies, Divino afflante spiritu. The encyclical incorporated Lagrange's most important ideas and made them official Catholic doctrine. It was a watershed for Catholic biblical studies, allowing for new translations based on the best ancient sources and acknowledging the plurality of literary genres in the Bible other than simply historical, an advancement that allowed Catholic schools to teach Darwinian evolution using a solution that Langrange had found back in 1903. It was also a watershed for Dominican-Jesuit relations. Dominican scholars at the École set to work creating a new translation of the Bible using modern biblical criticism, such as the four-source documentary hypothesis for the Pentateuch. It was published as the Bible de Jerusalem, complete with annotations, in French in 1955. Many biblical scholars assisted, but importantly for our story, the Jesuits made a significant contribution, especially Stanislas Lyonnet (1902-81) of the Biblicum.

The collaboration between the Dominicans and the Jesuits grew even greater at the Second Vatican Council. As the council began, Lyonnet and another Jesuit professor at the Biblicum, Max Zerwick (1901-75), were controversially forced to retire abruptly. Though they were soon reinstated, amidst this controversy, one of the Dominican periti, Pierre Benoit (1906-87) of the École, built a strong friendship with Lyonnet. To help overcome the negativity of the past, Belgian Jesuit Maurice Gilbert (b.1934) taught at the École and assisted with administrative plans.

Because of these friendships, the relationship between the Jesuits and the Dominicans in the area of biblical studies has greatly improved. The École was even offered the right to confer the three pontifical degrees formerly reserved to the Biblicum, but surprisingly decided to only offer one of them, the doctorate. But the Biblicum now allows students to study for a year at the École while they are pursuing their degrees, creating a good number of students to fill classes at the École and further breaking down barriers.

This sometimes contentious, sometimes collaborative relationship between the Dominicans and the Jesuits in modern biblical studies makes a strong case that when the Dominicans and Jesuits work alone or at odds with each other, their contributions to the wider church suffer, but when they collaborate, much can be accomplished to the benefit of all.

The most infamous example of a contentious relationship between the Dominicans and the Jesuits is the arguments about nature and grace documented 
in Robert J. Matava's article, "A Sketch of the Controversy de auxiliis." The roots of the controversy predate both the Jesuits and the Dominicans. They spring from tensions inherent in St. Augustine's (354-430) mature teaching on how God can help (auxilium) us to do good without taking away our free will. Augustine never resolved the tension. He was at a historically early stage in the development of these ideas, and these questions touch on the very heart of the mystery in revelation itself: the relationship between the efficacy of God's grace and the freedom of human choice even under the influence of grace, as well as the relationship between divine and human action. How do human persons remain free under the influence of God's grace?

After Augustine, perennial arguments about this question in the Latin church tended towards a predictable form with two sides, one side over-emphasizing God's sovereignty and the other crystallizing around an unbalanced commitment to human autonomy. The Council of Trent (1545-63) weighed in, siding with human freedom over and against the reformers such as Martin Luther (1483-1546) and John Calvin (1509-64) whom it believed erred on the side of divine sovereignty, denying free will.

The controversy flared up between the Jesuits and the Dominicans in 1582 in Salamanca, Spain, over a debate about whether Jesus laid down his life freely, and therefore meritoriously, given that the Father decreed that he lay down his life. The Dominican Domingo Báñez (1528-1604) argued that the Father predetermined this event just as he does all other free acts of his creatures, because what the Father predetermines necessarily comes to pass and has its desired effect. Against this view, the Jesuit Prudencio de Montemayor (d.1599) argued that if this were true, Jesus was constrained and would not have given his life freely, and thus there would have been no merit in his death.

Báñez and Montemayor accused each other of heresy. Báñez submitted several theses to the Spanish Inquisition for review that he claimed were Montemayor's. Then, in 1588 in Lisbon, the Jesuit Luis de Molina (1535-16oo) published a seven-hundred-page book on the topic, the Concordia. Molina argued that, for humans to be truly free - to be able to choose one thing or another on their own without external constraint - meant that even God could not predetermine the outcome of their decisions. Thus, an explanation needed to be given of how divine sovereignty could be reconciled with human free will. Molina solved the philosophical conundrum by proposing that God had a "middle knowledge" - that, as God knows all things, God knows how people will respond to any particular grace, and so God chooses to give the graces he knows will be accepted. Additionally, Molina proposed a theory of "non-determining divine concurrence," meaning that God, seeing how a person chooses, gives a grace that helps to bring about what the person has freely chosen. God's grace 
does not determine the person's decision but works along with ("concurs") the person to bring about the chosen good. Thus, grace is efficacious and people still choose freely.

In contrast, Báñez's understanding of the situation began with the conviction that God was the first cause of everything, even of human free will and the decisions that humans freely make. God works with humans to accomplish good not by waiting to see their decisions and offering grace to help bring them about, as in concurrence, but by giving a grace within people that helped them to choose what was best by reducing the possible options individuals could choose. This position was called "premotion" and it held that grace enhanced people's ability to choose, rather than supplanted it. For Báñez and the Dominicans, freedom is the ability to pursue the best course of action, not any random set of actions, so one's free choice is radically based in the intellect. Free choice depends on what one thinks about the world and the desirability of various options, so that is where premotion works most. On the problematic side, premotion also tended to implicate God in sin, since one could argue that if someone indeed chose to sin, God did not give sufficient grace.

Báñez immediately censured the Concordia when it came out, claiming that it asserted several propositions that had been deemed heretical by the Spanish Inquisition. Within a year, Molina's book was being investigated by the Spanish Inquisition even though it had been approved by the Portuguese Inquisition. A few years later, as tensions mounted, Molina denounced Báñez to the Inquisition, alleging that he maintained Protestant views condemned by the Council of Trent.

Over the next five years, the controversy spread throughout Spain, with Dominicans lining up with Báñez against the Jesuits who lined up on the side of Molina, creating voluminous writings on the subject. The Dominicans pointed out that if God was always responding to human free choice in giving grace, then God was not the initiator of all grace, as the church held. In response to this criticism, the Jesuits clarified their position by adding a theory called "congruism" that held that God, by foreseeing in his perfect middle knowledge how an individual would respond to particular graces that could be offered, chooses to give these graces under these circumstances, knowing that they will be efficacious for the desired outcome.

In response to the rising tensions between the Dominicans and the Jesuits, Pope Clement VIII (1536-1605; r.1592-1605) ordered all sides to stop the debate until he could determine who was in the right. After four years of collecting writings and soliciting opinions from various experts, the commission he set up to evaluate the issue hastily sided with the Dominicans against Molina. Dissatisfied with such a hasty decision, Clement called on the heads of both 
orders to come to Rome, attended by their own experts, to argue their cases in person and come to a compromise. After a year of discussions nothing was settled, since both sides preferred to attack their rival's position rather than expand their own views or find a compromise. So Clement decided to personally preside over yet another set of proceedings, which lasted for three years without success before Clement died in 1605. After the short reign of his successor, the next pope, Paul V (1550-1621; r.1605-21), resumed the proceedings, but was still unable to resolve the issue. Thus, in 1607, twenty-five years after the beginning of the de auxiliis controversy, Paul v called an official end to the controversy by affirming the tenability of both positions and banning the publication of books on the topic without the explicit approval of the Holy See. The disputants were to await a final resolution of the matter by the Holy See. As of today, more than four-hundred years later, that resolution has yet to come.

Our author, Matava, argues that ending the debate this way did not resolve it. The debate had long ceased to be about allowing the mystery to lead us all to a deeper truth and had become a partisan battle with each side intent on destroying the position of their opponent. Unlike the medieval disputatio, neither side was self-critical enough to seriously reevaluate its own position in light of the critiques of the other. While there were minor players in this debate that crossed over the lines, all of the major Dominicans in the debate were on one side and all of the major Jesuits were on the other side. As Matava sees it, "In fact, the de auxiliis question continued to haunt the church for centuriesas long as theologians were willing to think about it-and the question was never adequately answered. The Dominicans and Jesuits were fixated upon a substantive issue-a genuine theological mystery at the heart of the Christian faith - one which deserves the kind of sustained reflection and clear formulation that has been given to such mysteries as the Trinity and the Incarnation."

I take a slightly different view of the controversy as a whole. There are plenty of contrarians among both the Dominicans and the Jesuits-people who habitually take the other side of any position they encounter. For this reason, I find it striking that there is such a uniform polarization among Jesuits and Dominicans on this issue. I can think of no other issue where such is the case. As a Dominican, I have to admit that I read the Jesuit view with skepticism and the Dominican position with sympathy, if not outright acknowledgement. Yet, I do not think that this was merely tribalism. The Dominican view touched something more firmly rooted than that. I believe that the stubborn divide is due somewhat to the difference in our charisms, the fundamental reason why the two religious orders exist. The Dominican position made sense to me because it started where I generally start, sensing a deep collaboration between 
God and the world. The world is fallen, broken, but it is still basically good and permeated by God's grace. The Dominicans were created out of Dominic's battle to combat Albigensian views that the physical world was fundamentally evil and at war with the spirit. From the beginning Dominicans have held to this view of one-sided human and divine collaboration, where God's grace allows human nature to flourish and allows us to become the best version of ourselves. At the same time, Ignatius of Loyola $(c .1491-1556)$ began his ministry helping people discern and commit to doing God's will in their life, no matter the cost, and they have maintained this emphasis on individual responsibility ever since. I suspect that this would be why Jesuits would find it natural to start where Molina did, just like Dominicans would find it natural to start where Báñez did. I cannot tease out the nature vs. nurture aspect of whether these groups attract like-minded people or form them, but there are strong family resemblances aligned on these issues within both groups.

I also wonder if the issue has not already been "adequately resolved." As Matava points out, the way that grace works with nature to bring about the good in the world is fundamental to many areas of theology, so this is an important question. But perhaps there really are multiple viable solutions to how we conceptualize this relationship, each valid in itself and yet each contradicting the others such as to deny a middle position. We believe that God has revealed the truth to us in things that matter for our salvation, such as the Trinity. There are not four persons and one God, nor is there simply one person in God. The number is three, which we name Father, Son, and Holy Spirit. Christians disagree about this with Muslims and Jews, and it is a difference that matters enough to keep us apart in faith. But perhaps in matters such as the relation between nature and grace there is room in Christianity for multiple beliefs. It does not affect our ability to embrace the Nicene Creed. As we have seen, both views can be argued and squared with themselves and with the tradition. Do we, as a church, need to pick one over the other? It would be like asking which religious order is better, the Dominicans or the Jesuits. The question can be argued and has multiple answers, but the church is richer by not choosing sides and allowing the multiplicity to stand.

In the end, Matava recommends moving forward by reframing the central question of God's causality with a consideration of God's simplicity and creativity. Perhaps then we would find a solution that included the best insights from both sides. I would suggest instead that we move forward by embracing the diversity of views rather than reinforcing the belief that every question has but one solution.

More importantly, when one looks at the history of this controversy, one can see with Matava how much creative energy has been wasted by each side 
anathematizing the other. The arguments have had some good effects, getting each side to clarify its position, but so much more could have been accomplished. Each side dug in, spending most of its energy criticizing the position of the other rather than trying to see its good points, and each side refused to look critically at its own position in light of the other. This is the difference of moving away from a dialogue or a disputatio into an argument. One wants to win an argument. One wants to learn in a disputatio. We should move to the disputatio and let each side try to deeply understand the other view and the values at stake driving it. If Matava is right, such a sympathetic reading could spark new creativity that could overcome the difference. If I am right, such a sympathetic reading could let us see in what situations we might prefer to employ one view over the other, reinforcing the idea that we are richer for having multiple theologies that we can bring to bear in different situations. In either case, we can clearly see the negative effects of the conflictual relationship between the Jesuits and the Dominicans in this controversy. Progress will only come if we learn to respect one another and come together as colleaguescolleagues who differ, to be sure, but each deserving equal respect.

\section{$3 \quad$ Exercising the Exercises}

Terence O'Reilly gives us an article about two prominent Spanish Dominicans, Melchor Cano (c.1509-6o) and Tomás de Pedroche (d.1569), who condemned as heretical Ignatius of Loyola's Spiritual Exercises. The Exercises, together with the book that explains how to give them, the Official Directory (which was compiled forty-three years after his death), are the most important documents defining the unique spirituality of the Jesuits. In opposing the Exercises, Cano and Pedroche implicitly condemn Ignatius himself and thus the entire Society of Jesus that he founded. In this way, the acrimony of this debate surpasses that of the de auxiliis controversy.

Ignatius's Exercises are a guide to an extended retreat meant to foster spiritual discernment and lead people to a deeper commitment to following Christ. Ignatius originally developed them in the 1520 s while still a layman in Spain as Spain experienced a series of lay-led religious revivals, most notably the Erasmians and the Illuminists. Desiderius Erasmus (1466-1536) published his Enchiridion in 1525 in Alcalá, Spain while Ignatius was a student at the university there. Its theme that "piety is not the preserve of the monk" gave rise to a reform group called the Erasmians, who advocated a piety based on interior prayer, the imitation of Christ, and knowledge of Scripture rather than on the official liturgies and sacraments of the church. Unlike the Erasmians, 
the Illuminists drew inspiration from monastic traditions of contemplation, asserting that the incipient union with God that contemplation affords was accessible to all. Ignatius was a member of neither group, though many of his friends had connections with these groups, and while the Exercises are different in vocabulary and tone from the Enchiridion and the writings of the Illuminists, they share a focus on one's relationship with God in a lay context, with few references to the sacraments and the liturgy of the church.

The Erasmians and the Illuminists both ran afoul of the Inquisition. Cano and Pedroche argued that the Exercises should also be condemned for teaching the same ideas. O'Reilly identifies three particular areas that Cano and Pedroche most objected to: a universally available call to contemplation that would include lay people, a reliance on the experience of spiritual joy and consolation in discernment of God's will, and a trust in the experience of being guided by the Holy Spirit.

The Exercises were developed by Ignatius to renew the faith of lay people. Cano argued that it was not right to encourage lay people to pursue contemplation since their proper call was to an active life of doing good works. For Cano, the hours spent in contemplation could get in the way of their accomplishing good works. He argued, "If the cobbler, on making the Exercises, were to sew the shoe less efficiently, and if the cook were to prepare the stew badly, we would find it insufferable, however much it was claimed that they were given to devotion and meditation."

The Exercises, like the Illuminists, also value the experience of spiritual joy, against a traditional piety centered on sorrow for sins and sanctioned rituals and devotions, which the Illuminists characterized as tedious. Instead of worrying about ritual requirements and attending to sacraments, Ignatius noted that retreatants should feel consolation and desolation as they make their way through the Exercises. He particularly noted the importance of a "consolation without preceding cause" as an indication that God was pointing out something important to the retreatant. Against this, Pedroche argued that consolation and joy in prayer were often given to beginners, as one would give a child a toy, to encourage those less advanced and less dedicated. They should not, therefore, be used as a gauge for faithfulness. True devotion is found not in those who experience joy in prayer but in those who dedicate themselves to carrying out the commandments, especially when they are difficult. Cano added that it was unclear where any particular spiritual consolation came from, so it could be given as a trick of the devil to lead people down the wrong path. Thus, we should tell lay people that the road to holiness is difficult and takes much work, lest they turn to prayer out of laziness and for undeserved consolation. 
The Exercises are meant to help retreatants find divine guidance from the Holy Spirit about the direction of their lives by helping them to recognize the Holy Spirit acting within them. By encouraging a selfless love of God, people acquire a sensitivity to the promptings of grace within themselves. Cano countered that expecting God to speak to oneself directly was to tempt God. Rather, if one wanted to know the will of God, one should consult learned men and use one's God-given intelligence to figure it out, lest one think that anything that occurs to one might be from God. Such a path is rife for self-delusion and exploitation by the devil.

In one sense, the criticisms of Cano and Pedroche had little effect. The Exercises continued to flourish even in the towns where Cano and Pedroche preached and were even granted papal approbation. But other conservative voices across Europe joined Cano and Pedroche in their suspicion of the Jesuits, and Ignatius was keenly aware of this rising tide of opposition and moved to protect his order. There is circumstantial evidence that Ignatius might have edited the Exercises in order to remove references to the Holy Spirit that might have been construed as illuminist.

A high-water mark for opposition to suspicious ideas came in 1559 when Pope Paul IV (1476-1559; r.1555-59) published the dreaded Index of Prohibited Books. But by 1560, Ignatius, Cano, and Paul IV were all dead, and the agenda they had set began to work itself out in the way the Jesuits argued about how to define and use correctly the terminology of the Exercises that Ignatius had bequeathed so as not to run afoul of the church. A "directory" is a companion book to the Exercises interpreting it and containing instructions for the director guiding the retreat. When Ignatius died, he had left only a minimal directory, so the Jesuits set to work to create a better one. The directories written between 1560 and 1590 show a large variety of interpretations of his work, including divergent views in exactly the three areas that Cano and Pedroche criticized. Moreover, the discussions among the Jesuits adopted the terms and categories that Cano and Pedroche set. These differences were resolved in 1599 with the publication of the Official Directory, which set the canonical boundaries on interpretations of the Exercises and defined a specifically Jesuit spiritual discourse. Thus, Cano's and Pedroche's criticisms, while not having much direct effect, seem to have guided the development of Jesuit spirituality in the early years of the Society.

O'Reilly notes that scholars are currently reevaluating the mystical and spiritual aspects of the Exercises, so it remains to be seen whether these Dominican interventions served to clarify Ignatius's thought or distort it. For instance, while the received wisdom is that consolation without preceding cause was an unimportant limit case that almost never occurred, it is now seen as an integral 
part of the theology of the Exercises. Was the significance of this concept buried because of Dominican criticism?

This shows the danger of how a contentious relationship between the Dominicans and the Jesuits could negatively impact the effectiveness of ministries. Cano was not successful in suppressing the Exercises or its revitalization of the prayer life of lay people. I am glad that this is so. I would hope that I would be happy if the cobbler did not fix my shoe in time because he was caught up in ecstatic prayer; and I believe that God can speak directly to people in such a way that all spiritual wisdom should not have to be mediated through designated human experts; and the consolation that comes in prayer is sometimes the only thing that gives people the strength to go on another day on the right path, so I would not oppose it as does Cano. Cano points out how prayer could be problematic if distorted, but surely the best solution is not to simply leave prayer to the experts. Yet, these arguments are still repeated today by Dominicans who hold that religious life is a "higher" form of life. So, the argument continues, though mostly underground and so not so overtly contentious. Does it have any effect other than a self-congratulatory reconfirming of beliefs of those on both sides? Is anyone listening?

4

Mary and the Turks

Next, in "Our Lady of Victory or Our Lady of Beauty?: The Virgin Mary in Early Modern Dominican and Jesuit Approaches to Islam," Rita George-Tvrtković contributes an article about the different ways Jesuits and Dominicans dealt with Muslim incursions into Europe in the late sixteenth century. Both employed images and stories about Mary, the mother of Jesus, but in very different ways.

The rise of the Ottoman Empire and its encroachment into Europe in that period provoked a reaction from the church to deal with them by either conversion or conquer. At that point, Dominicans had been working as missionaries among Muslims for over three hundred years, with friars such as Ramon Martí (c.1220-85) in Spain, Riccoldo da Montecroce (c.1243-1320) in Iraq, and William of Tripoli (c.1220-73) in the Holy Land having lived among Muslims, learning Arabic and studying the Qur'an in its original language, so they were in a good position to deal with Muslims. The Dominicans also had the rosary, a popular devotional prayer invoking the help of Mary which by legend had been given to St. Dominic (c.1170-1221) by Mary herself, a legend probably created two-hundred years later by the popularizer of the Dominican rosary, Alain de la Roche (c.1428-75). Starting with Roche, Dominicans formed groups of lay 
people in cities across Europe with huge success, centered around praying the rosary, communal prayer, personal piety, and corporal life. For instance, in just seven years after its founding, the rosary confraternity in Cologne numbered 100,00o. Pope Pius V (1504-72; r.1566-72), a Dominican, eventually declared the Dominican version of the rosary standard for the universal church, proclaiming it to be a useful tool against Muslims, Protestants, and all the enemies of the faith, recounting a legend of St. Dominic using the rosary to defeat the Albigensians.

Then, on October 7,1571 , against great odds, the Catholic League defeated the Ottoman Empire's naval forces in the Battle of Lepanto. It was rumored that the commander of the fleet kept a statue of Mary on his ship for protection, and the Dominican chaplains of the fleet had been encouraging the soldiers to pray the rosary. Pope Pius v explicitly attributed the victory to Mary's intercession, citing the prayers of Rome's rosary confraternities, and he created a new feast day, Our Lady of Victory, to be celebrated in perpetuity every year on the anniversary of the Battle of Lepanto. The following year, the next pope changed the name of the feast to "Our Lady of the Rosary," but the intention remained the same.

The Battle of Lepanto sparked a tidal wave of artwork dedicated to Our Lady of Victory, from plays to processions to ballads to murals, all hailing how Mary had interceded to help defeat the "godless" enemies of the church. The Dominicans embraced Our Lady of Victory. They sponsored an annual procession through the streets of Antwerp, and on its centenary the rosary confraternity commissioned four paintings of the Battle of Lepanto for the Dominican church there. In a nod to Our Lady of Victory being effective against all of the foes of the church, the painting of the battle depicts enemy ships flying not only the flags of the Ottoman Empire, but Protestant banners as well. In a more disturbing example, the cover of a seventeenth-century pamphlet from a Dominican rosary confraternity in Cologne, bears the image of Mary standing atop a headless Turk, holding the baby Jesus in one hand and a sword encircled by the rosary and the words "shield of Christians" in the other. The baby Jesus holds the dead Turk's bloody head. Instead of "pray for us," the writing around Mary implores her to "fight for us."

The Jesuits occasionally took up the image of Our Lady of Victory as wellfor instance, writing a play entitled "The Triumph of the Virginal Mother of God" for performance in German-speaking lands-but they were much more likely to embrace a different image of Mary, which George-Tvrtković calls "Our Lady of Beauty." Instead of combating Muslims, Jesuit missionaries in Islamic lands were instructed by their superior generals to focus on caring for local Christians and dealing with Muslims benignly. Jesuits did this by leveraging 
the reverence for Mary that is shared by Christians and Muslims. Mary is an important figure in the Qur'an. One of the chapters is named after her, and she is venerated by many in Islam as the virginal mother of the prophet Jesus. This connection had been noted by William of Tripoli, but the Dominicans who promoted the rosary and Our Lady of Victory did not live among Muslims or know the Qur'an as did William, and so were unaware of this connection. The Jesuits in Islamic lands used this connection to try to attract Muslims to Christianity by creating beautiful and compelling icons of Mary for Muslims and by highlighting Mary's role in conversion stories.

The Jesuits befriended the Mughal emperors Akbar (1542-1605) and Jahangir $(1569-1627)$ who were quite interested in Christianity and adorned their palaces with images of Jesus and Mary. These emperors also assisted the Jesuits' work by financing an art studio that created icons of Mary fusing classical Persian and Italian Renaissance artistic traditions, up to half of which were destined for Muslim buyers. The emperors also commissioned a Jesuit, Jerónimo Xavier (1549-1617), to write the text for an illustrated book of the life of Christ. Xavier's text, the Mirror of Holiness, written in Persian, goes far beyond the biblical text in expounding on the life Mary, including accounts of the annunciation of Mary's birth to Anne, Mary's nativity, her seclusion in the temple as a young girl, and her virginity. These excesses were noticed by a Protestant critic in Europe, who published a Latin translation of the Mirror of Holiness with the subtitle "corrupted in many ways," and an appendix of over onehundred pages noting Xavier's errors in biblical exegesis and misuse of extrabiblical sources, dismissing the entire Jesuit missionary project as preaching Mary more than Christ.

While the number of Muslim conversions to Christianity due to the invocation or intercession of Mary is unknown, there is one famous example. The Muslim prince Baldassarre Loyola Mandes (1631-67) converted to Christianity and became a Jesuit, attributing his conversion to frequent apparitions of Virgin Mary through all phases of his life: convincing him to become a Christian, choose the Jesuits, stay the course he had chosen, and eventually to work to convert more Muslims to Christianity, which he did, of course, with recourse to Our Lady of Beauty. Later Jesuits would celebrate Baldassarre's life and highlight the importance of Our Lady of Beauty in his conversion as proof of the effectiveness of this approach.

While there was overlap in the use of these two images of Mary in dealing with Muslims in the early modern period, it is clear that the Dominicans played a central role in shaping the use of Our Lady of Victory while the Jesuits were largely responsible for pioneering the use of Our Lady of Beauty. And while neither of these images seem to have been very successful in converting or 
conquering Muslims, they are both very much alive in the Catholic imagination today. There are websites that encourage Catholics to pray the rosary to defeat Muslims, especially terrorist organizations such as Al Qaeda and IsIs. Catholics engaged in dialogue with Muslims still have recourse to Our Lady of Beauty, though as a bridge to foster communication rather than as a lure to conversion.

One could wonder if the Dominicans coalesced around the combative icon of Our Lady of Victory because of their corporate commitment to the rosary and their connection to Pope Pius v, or because they had largely curtailed their work in Muslim countries. After all, it was the Jesuits working in Muslim countries that were actively discouraged from using antagonistic images such as Our Lady of Victory and so developed the softer, attractive approach of Our Lady of Beauty. But Jesuits did make use of Our Lady of the Rosary in German-speaking lands against Lutherans and in Brazil against heretics, and they connected Mary to military action against Muslims after the Ottoman siege of Vienna.

Rather than being segregated by religious order, perhaps Catholic clerics simply chose the image that best fit their situation, with those who perceived that they were on "home turf," designating Muslims and Protestants as "foreigners" and "usurpers," by and large choosing the militaristic image of Our Lady of Victory to help them beat back the hostile forces, while those Catholics who perceived themselves as foreigners working in hostile territory sought the help of Our Lady of Beauty, who assured others that we are all the same and posed no threat. As for the relation between Dominicans and Jesuits, in this case, there was not a lot of it. The two groups seemed to be like ships passing in the night, there on the same sea but unaware of and unconcerned for what the other was doing. There is much more sharing within each group than between them. One wonders if more could have been accomplished with greater collaboration.

Our final paper in this issue is about what can happen when Jesuits and Dominicans work well together. Thomas O'Meara gives us “Dominican and Jesuit Theologians at an Ecumenical Council: Yves Congar and Karl Rahner." These two great theologians, one a Jesuit and one a Dominican, worked together to help shape the great documents of the Second Vatican Council (1962-65), each seeing the other as a valuable ally in the fight to move the church forward into the modern world, against traditionalists who were seeking to maintain the status quo. 
The period after the Second World War (1939-45) was one of growth and change for the church and the world. Catholics called for change in response to a changing world, and theologians responded in the areas of ecumenism, biblical study, pastoral and liturgical renewal. New ideas provoked disciplinary actions issued by the Vatican against some theologians, but this only encouraged them to work harder for renewal in the church, and at the Second Vatican Council, many of these new ideas were incorporated into official Catholic teaching.

The council was composed of bishops from around the world, representatives of other Christian churches, and periti, theological experts on various subjects. Two periti in particular stood out: Yves Congar (1904-95), who was the most influential theologian leading up the council, and Karl Rahner (1904-84), who became the most influential theologian moving forward. These two theologians worked together and became friends at the council. Congar saw Rahner as a great ally and spoke of Rahner with admiration in his diary of the council, writing at one point that Rahner had probably spoken too much, yet he was magnificent, courageous, and profound. Later, when one of the more conservative Vatican officials angrily confronted Congar about sharing Rahner's views, Congar said that he had not worked on the issue in question but that Rahner was a friend.

Congar studied the history of the structures and the teachings of the church and was a pioneer in ecumenism. His ideas had direct bearing on sections of the final texts of the council in the documents on the church, revelation, ecumenism and other religions, priesthood, religious liberty, and foreign missions. Karl Rahner was a fundamental theologian attentive to the thought-forms of Thomas Aquinas (c.1225-74), Immanuel Kant (1724-1804), and Martin Heidegger (1889-1976). Rahner showed the conciliar theologians how to be faithful to the Catholic tradition and in touch with the modern world. Rather than contributing ideas one could pin down, Rahner showed the council fathers how to rethink the tradition in a way that could make use of the best insights from the modern world to create a deeper view that could speak to the concerns of the modern world. Rahner's comments on an early schema of the innovative document on the church in the modern world, Gaudium et spes, is indicative of the depth of his vision: he wrote that the document was too positive, lacking a serious theology of sin; it was too abstract, lacking a fundamental theology of how average Christians reflect on the world; its tone remaining serenely apart from the world; it should state the limits of faith when trying to discern concrete moral problems; and it needed attention to the relationship between the order of creation and the order of salvation, bringing out the divine goal of elevating the world to God. Congar's contributions to Gaudium et spes showed many of the same concerns. Congar and his confreres had worked 
with those who were socially impoverished and alienated from the church in an attempt to build a theology that could speak across this divide, creating a bridge to bring these people back in touch with the church and more integrated into society. Congar believed that a renewed anthropology based on people being made in the image of God could serve as this basis and provide a foundation for Christian ethics. Both Rahner and Congar agreed that there was no part of the secular world outside divine grace, and no part of the church outside human truth. Both worked to knit together the sacred and the secular, and with their combined effort this turned out to be the goal of Gaudium et spes as well.

These two theologians were also influenced by their respective Dominican and Jesuit spiritualities. Congar wrote a bit on Dominican mystics, but generally considered Aquinas's theology to be the foundation of Dominican spirituality. Rahner was faithful to the vision of Ignatius of Loyola but had aspects of Thomistic spirituality stemming from Aquinas's great influence on the Society of Jesus. Their other shared source of spiritual discernment was the modern world they inhabited. Both believed that grace exceeded the boundaries of Christianity.

For a festschrift honoring Rahner in 1979, Congar wrote a lighthearted letter pretending to be from Aquinas to Rahner. Along with a dig at Rahner's rather verbose, Germanic style (very different from Aquinas's), Congar/Aquinas approved of Rahner's basic insight that the world is permeated with grace such that every person, inside and outside the church, exists in a real order of salvation. He finished the letter by embracing Rahner as a brother, commending how he has formulated so many issues anew.

After the council, Rahner commented that the church of the future would have a different form than the present church, having a greater pluralism and consisting of a network of basic communities whose inter-relationship was assured by the bishop. Congar and Rahner as well as other Dominican and Jesuit theologians working at the council took a broad step in this direction in the ways that they put aside former rivalries and worked together to help forge the truly remarkable achievements of the Second Vatican Council. Rather than allowing their differences divide, they came together over their common love for the church and for truth and leveraged their differences to explore more deeply the truth that is beyond either of their individual perspectives.

At the opening of the twentieth century, after a few years of initial collaboration the Jesuits actively opposed the flourishing of the École Biblique, the 
Dominican project renewing biblical studies in the Holy Land, creating their own rival institution and publications in Europe. For forty years there was a contention between the two groups in biblical studies until two key scholars, one Dominican and one Jesuit, finally worked together on the important encyclical about interpreting the Bible, Divino afflante spiritu. The thaw in the relationship expanded, allowing Jesuits and Dominicans to collaborate on the Second Vatican Council's Dei verbum, and today the two schools collaborate in educating the next generation of scripture scholars. The advantages for the advancement of biblical scholarship of a good relationship between these two groups are obvious, but they were just as obvious back in the days when they opposed each other. What changed?

Untold human effort and copious bottles of ink were spilled over the controversies about God's grace and human free will. While the disagreement prompted both sides to think more deeply, clarifying their position, which is good, it also prompted them to circle their wagons, banding together along tribal lines-Jesuits against Dominicans-in unified efforts to oppose a hostile enemy. Neither group as such attempted to see the good in the position of the other side and to use that insight for a serious critique of their own position or to incorporate it into a more balanced view that drew from the best ideas on both sides. The situation was so bad that the groups were ordered simply not to fight about it anymore for the sake of peace in the church. After four-hundred years, this detente is the best we have mustered. Is it the best we can do?

There is a possibility that there is no articulatable middle position, simply two different approaches that are unbridgeable due to the unfathomable mystery that is God's grace working in our lives. But lacking a deep and sympathetic dialogue between these two sides, we have no way of knowing this. Imagine what could be learned if we gave up the tribalism and worked together to find the greater truth at the heart of this mystery.

Two Dominicans vehemently denounced the Spiritual Exercises as heretical, seeking to get it banned from the church. They were unsuccessful but never repentant, and it seems that what they might have accomplished was to obscure some of St. Ignatius's spiritual brilliance for a few hundred years.

The Dominicans and the Jesuits worked separately in dealing with Muslims in the early modern period, even though they had many overlapping ideas. They probably could have accomplished more in collaboration. One of the papers that was not written for this issue was about the relations between the Jesuits and the Dominicans in their missions to China. To reason no one wanted to touch it is that our understanding of this history is changing at the moment. While the received wisdom is that they were on opposite sides of a "rites controversy," it seems now that they were just pursuing very different paths. 
The Jesuits were in one part of China working with intellectual elites, while the Dominicans were in another part of China ministering among the working class, and the two orders had very little communication or coordination between their efforts. When things fell apart for political and social reasons, they were in no position to work together to try to salvage something from what had been accomplished.

The one really positive story related here was the collaboration between Rahner and Congar at the Second Vatican Council. It is a shining example of what can be accomplished when the two groups, while maintaining their differences, work together to accomplish a difficult task.

In ecclesiology, biblical studies, and in the de auxiliis controversy, Jesuits and Dominicans of today are less interested in maintaining old rivalries than in working together to find the best solutions to the difficult problems facing the church today. If at times the church had the leisure to squander resources in a squabble among siblings about who was best, these are not such times. The issues that face the church and the world today are large and looming. Jesuits and Dominicans have come to see the advantage of working together to find creative solutions, maintaining their own unique traditions so that they have a variety of perspectives to bring to bear on any issue.

Many of us also have our own stories to tell. I am a member of the Midwest province of the Dominicans. In 1981, we relocated the Aquinas Institute of Theology, our primary school of theology, from Dubuque, Iowa to St. Louis, Missouri to be next to St. Louis University, which was sponsored by the Missouri Province of the Jesuits. In a shocking example of ecumenism (I jest, but only slightly), the two schools combined their theological libraries. There are few things that Jesuits and Dominicans are more protective of than their books. Combining these libraries was a prophetic sign of a much deeper collaboration and trust between the two groups. This collaboration has not always been without tension, but it has been beneficial for both sides and for promoting the study of theology and philosophy in the region. Two schools of theology, each maintaining its own tradition, living side by side, collaborating and sharing resources - this is a relationship that benefits our common mission to bring the Good News to the world.

Perhaps we are not quite at the dawning of the Age of Aquarius, but there does seem to be a shift in relations from contention to collaboration. At the very least both groups should be able to agree that when their relationships turn rivalrous or hostile because of some particular issue, they should stop and take notice. That kind of negative energy has not served them well in the past, and it is most likely not the best way to accomplish the greatest good. But what about pursuing a broader collaboration? In many ways, the Dominicans and 
the Jesuits are like ships passing in the night. Each group has enough work and enough trouble enough of its own to have much energy left to spend in building relationships that do not have a clear and present advantage. Few people either within or outside the church make collaboration with others the default mode of accomplishing goals. It often seems easier to simply get the job done with the resources available. But the good that the Dominicans and the Jesuits have accomplished when they have worked together should make us question this assumption and lead us to explore more broad collaborations. This would be difficult, requiring real structural changes, so it is improbable. But stranger things have happened. In 2016, the Master of the Order of Preachers, Bruno Cadoré (b.1954), was invited to preach at the Mass of the Holy Spirit before the election of the current Jesuit Superior General. While some might think this in itself an improbable event, it is actually in accord with a tradition dating back to 1600 in which the master general of the Dominicans celebrates the funeral mass for the superior general of the Jesuits. ${ }^{1}$ Cadoré's preaching, however, was quite relevant to our current discussion. It centered on the "audacity of the improbable," trusting in God, despite all odds, to bring about the good things that we cannot do on our own. He said that, while having the audacity of the improbable was essential to the Jesuit mission "to live as men of faith, contemplatives in action, men whose lives will truly be given for others," we learn to do it in our personal lives as we forgive one another in the day-to-day, "which makes us discover that in ourselves we have a life that is so much stronger, so much more beautiful, than the one we thought we possessed, a life which finds its full truth when it breaks away from the self to be offered to the other." ${ }^{2}$ The outgoing superior general of the Jesuits, Arturo Sosa (b.1948), amplified these words in his homily for the Mass of Thanksgiving at the end of the process, adding, "our audacity can go even further and seek not just the improbable, but the impossible, because nothing is impossible for God."3 Might the Dominicans and Jesuits learn to offer themselves to one another, forgiving the past in order to make possible a better future for the church? It may be improbable, but nothing is impossible for God.

1 Joseph A. Slattery, "In Memoriam: Very Rev. Fr. Vladimir Ledochowski 26th General of the Society of Jesus Oct. 7, 1866-Dec. 13, 1942," The Woodstock Letters, 72, no.1 (1943): 1-20, here 7.

2 Society of Jesus, 36 th General Congregation Documents, private edition (Rome: General Curia of the Society of Jesus, 2017), 70.

3 Society of Jesus, 36 th General Congregation, 73 . 